\title{
BRYOPHYTE FLORA OF THE AREA OF THE SETTLEMENT OF SELINA (ISTRIA, CROATIA)
}

\author{
Dino Babić \& Antun Alegro* \\ Division of Botany, Department of Biology, Faculty of Science, University of Zagreb, Marulićev trg 20/II, \\ 10000 Zagreb, Croatia
}

Babić, D. \& Alegro, A.: Bryophyte flora of the area of the settlement Selina (Istria, Croatia). Nat. Croat. Vol. 28, No. 1., 73-88, 2019, Zagreb.

The bryophyte flora in the settlement Selina and the surrounding area (western Istria) was surveyed during the vegetation season of 2014. Altogether 66 mosses and 6 liverworts were recorded. Phytogeographically, the most abundant species are of the temperate zonobiome, i.e. circumpolar species, with respect to eastern limit categories. Analysis of bryophyte flora through habitat types shows that the highest species richness occurs by shaded rocks and in crevices, while the lowest richness occurs on arable land and occasionally the flooded banks of ponds. Regarding species composition, habitat types are clustered in four basic groups. Based on Ellenberg's ecological indicator values for light, moisture, reaction of substrate and amount of nutrients, the differences between bryophyte floras of different habitats are explained using methods of descriptive and multivariate statistics.

Key words: mosses, liverworts, biogeographical elements, habitats, ecological indicator values

Babić, D. \& Alegro, A.: Flora mahovina na području naselja Selina (Istra, Hrvatska). at. Croat. Vol. 28, No. 1., 73-88, 2019, Zagreb.

Flora mahovina istraživana je na području naselja Selina i okolici (zapadna Istra) tokom vegetacijske sezone 2014. Ukupno je zabilježeno 66 vrsta pravih mahovina i 6 vrsta jetrenjača. Fitogeografski, najbrojnije su vrste umjerenih zonobioma, odnosno cirkumpolarne vrste s obzirom na istočnu granicu areala. Analiza vrsta prema staništima ukazala je na najveće bogatstvo vrsta na zasjenjenim stijenama i pukotinama stijena, dok najmanje bogatstvo vrsta imaju obradive površine i povremeno plavljene obale lokvi. S obzirom na sastav vrsta staništa su se grupirala u četiri skupine. Na temelju Ellenbergovih ekoloških indikatorskih vrijednosti za svjetlost, vlagu, reakciju tla i količinu hranjivih tvari objašnjene su razlike $u$ flori različitih staništa metodama deskriptivne i multivarijatne statistike.

Ključne riječi: prave mahovine, jetrenjače, biogeografski elementi, staništa, ekološke indikatorske vrijednosti

\section{INTRODUCTION}

Bryological investigations in Istria have a long, but sporadic history, starting at the beginning of the $19^{\text {th }}$ century (Hoppe \& HoRnschuH, 1817-18) and continuing through the century (Host, 1831; Rabenhorst, 1844-53; SEndTner, 1857; Weiss, 1866, 1867; Tommasini in Freyn, 1877; Solla, 1891; and Kern, 1896), although some of the cited authors quoted very low number of species. A very fruitful period for bryological research was the beginning of the $20^{\text {th }}$ century, when a significant number of papers were published (GŁowACKI, 1902; LoITLEsBerger, 1905, 1909; Матоusснек, 1900, 1901, 1904, 1905). The most important researchers of this period were SCHIFfner $(1909,1915)$ and J. Baumgartner. The latter collected

\footnotetext{
* corresponding author (antun.alegro@biol.pmf.hr)
} 
a huge amount of herbarium material but did not publish the data; therefore, these data are scattered throughout the papers of other authors (e.g. ONNo, 1948) or still unpublished. Pavletić (1955) summarised all the available bryological data of the whole of the former Yugoslavia and his work became an important source of historical data for Istria as well. Unfortunately, after this work, bryological research in Istria almost completely ceased. The only further published notes are those from BIsCHLER \& Jovet-Ast (1973) who reported some findings of liverworts, DüLL (1999) who reported findings from several field trips, and Pericin \& HürLIman (2001) who published the microdistribution of bryophytes in one karst doline. More popularly, BERG in RotTENSTEINER (2018) quoted the commonest bryophyte species through the different habitat types. Hence, our research is one of the first detailed bryological surveys in Istria after many decades.

The objectives of this research were to collect herbarium material and use it as a basis to create a complete list of bryophyte flora in the settlement of Selina. This list was then used to perform a phytogeographic analysis of the flora, to analyse the flora according to the occupied habitat, and to perform an ecological analysis based on Ellenberg's ecological indicator values.

\section{Study area}

Selina (240 $\mathrm{m}$ a.s.l.) is a settlement situated in the western part of Istria, $4 \mathrm{~km}$ northwest from the head of Lim Channel between the towns Poreč, Pazin and Rovinj (Fig. 1). The geological bedrock belongs to Lower Cretaceous limestones with small intrusions of breccia, dolomite and feldspars covered mostly by terra rossa (PoLšAK \& ŠIKIĆ, 1969, 1975). The relief is rolling and covered with numerous karst dolines. According Köppen's climate classification and in line with the geographic distribution of climate types in Croatia, the predominant climate in Selina is $\mathrm{Cfb}-\mathrm{a}$ moderate, warm, moist climate with warm summers (FILIPČIć, 1998). The mean annual temperature in neighbouring towns is $13.4^{\circ} \mathrm{C}$ in Rovinj (13 km to the SW), and $11.3^{\circ} \mathrm{C}$ in Pazin (16 km to the NE), and the annual amount of precipitation is $811.5 \mathrm{~mm}$ in Rovinj and $1086.4 \mathrm{~mm}$ in Pazin for the climatic period 1961-1990 (Zaninović et al., 2008). Phytogeographically, Selina belongs to the sub-Mediterranean zone of the Mediterranean region (Nikolić \& Topić, 2005) characterised by thermophilic downy oak forests (Quercetea pubescentis DoingKraft ex Scamoni et Passarge 1959) represented by the association with eastern hornbeam (Carpinus orientalis Mill.), Querco pubescenti-Carpinetum orientalis Horvatić 1939, characteristic for the lower Submediterranean belt (VUKELIĆ, 2012). In the area of Selina however, this community is rarely present as a fully developed forest due to long-term anthropogenic influence. Instead, formations of coppiced woodland and scrubland belonging to the same association are more commonly present in the landscape. The grasslands of the area are seminatural, belonging to the Amphiadriatic dry steppic sub-Mediterranean grasslands of the Prealpine, Illyrian and Dinaric regions (Scorzoneretalia villosae Kovačević 1959), represented by meadows (Scorzonerion villosae Horvatić ex Kovačević 1959) and rocky pastures (Chrysopogono grylli-Koelerion splendentis Horvatić 1973 and Saturejion subspicatae 
Tomić-Stanković 1970) (Horvat et. al., 1974; ŠUgAR, 1984; KAligARIČ, 1997; TERZI, 2011; Mucina et al., 2016; ŠKvorc et al., 2017). Apart from these main vegetation formations however, many other habitats like arable fields, vineyards, olivegroves, orchards, paths, ponds, rocks, stone-pits, dolines and drystone walls are present in the area.

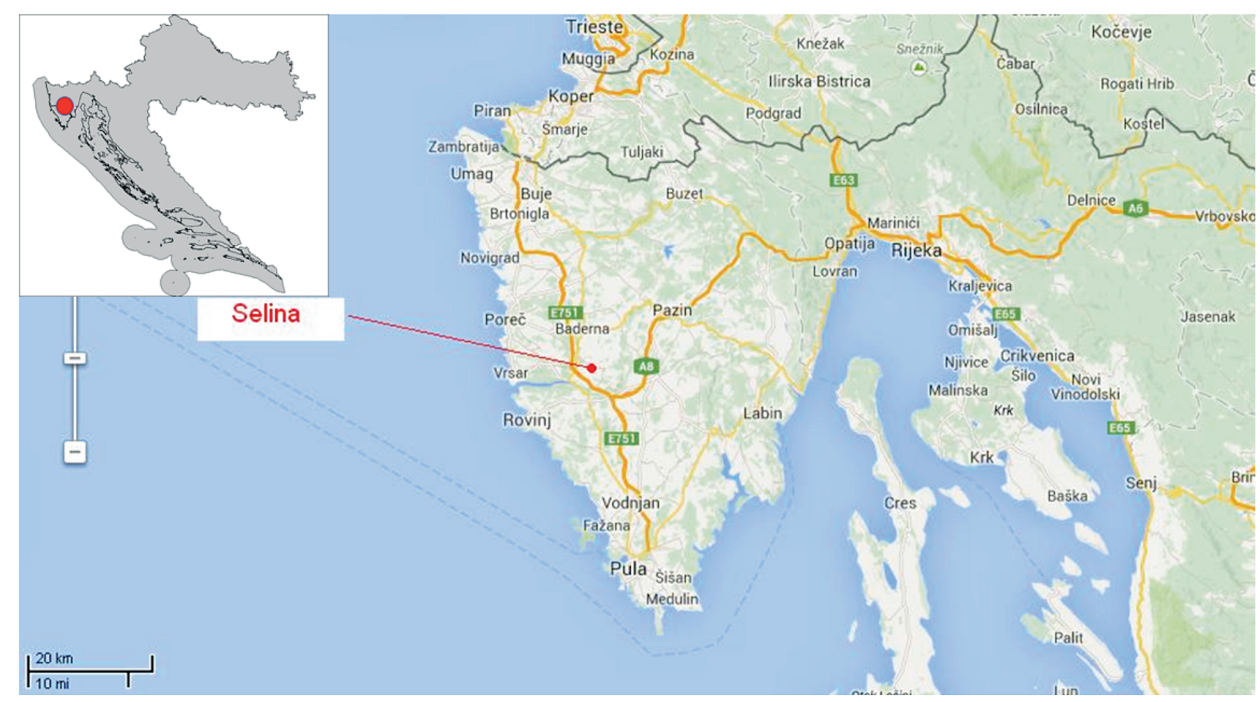

Fig. 1. Area of research: position of the settlement of Selina in Istria.

\section{MATERIALS AND METHODS}

Field research into bryophyte flora was carried out during the vegetation season 2014, from May to September. Multiple visits of all habitat types were carried out to record bryophyte species and their distribution (Tab. 1, Fig. 2). All species were collected and herbarized for subsequent identification. Standard determination keys and iconographies were used to identify the species: ATHERTON et al. (2010), Frahm \& Frey (2004), Frey et al. (2006), Smith (1990), Smith (2004), Ignatov \& Ignatova (2003-2004), Maier (2009), Casas et al. (2006), Guerra et al. (2006), ERzberger \& SCHröder (2013) and LüTH (2006-2011). The nomenclature of bryophytes was aligned with Ros et al. (2007, 2013).

The system of biogeographic elements (floristic elements or geoelements) groups the taxa according to the similarity of their distribution ranges. In this paper, each taxon is associated with the category of floristic elements according to Hill et al. (2007), composed of distribution type regarding major biomes and eastern limit categories.

For each taxon, the associated habitat type was also recorded. The habitat types were grouped as follows: forest (including scrubland) ground and dead wood (st1), grasslands (st2), arable fields (st3), ruderal habitats (st4), rocks exposed to sunlight and rock crevices (st5), shaded rocks and rock crevices (st6), epiphytes on trees (st7), artificial substrata (st8) and periodically flooded banks of ponds (st9). 
Furthermore, Ellenberg's indicator values (HiLl et al., 2007) for light (L), moisture $(F)$, environmental acidity $(\mathrm{R})$ and nitrogen or general fertility $(\mathrm{N})$ were assigned to each taxon.

To compare different habitat types regarding the composition of bryophyte flora, cluster analysis with the UPGMA (unweighted pair group method with arithmetic mean) clustering method was performed. Statistical significance of branchings in the dendrogram was tested using Simproff test with 100 permutations. NMDS analysis (non metric multidimensional scaling) with passively projected vectors representing ecological indicator values was used to explain ecological requirements of species through habitats. In both analyses, the Bray-Curtis index of similarity was used.

Cluster analysis was performed using the program package Primer 6.0 (CLARKE \& GORLEY, 2006) while NMDS was performed using NMDS in PcOrd 6.0 (McCunE et al., 2011).

Tab. 1. Geographical position of collecting sites.

\begin{tabular}{|c|c|c|c|}
\hline & Locality of collection & $\phi$ & $\lambda$ \\
\hline 1 & Courtyard in the settlement & 45.15705 & 13.77165 \\
\hline 2 & Courtyard in the settlement & 45.15796 & 13.77379 \\
\hline 3 & Scrublands dominated by Juniperus oxycedrus & 45.15986 & 13.77767 \\
\hline 4 & Grassland & 45.16197 & 13.78296 \\
\hline 5 & Forest of Quercus pubescens & 45.16428 & 13.78307 \\
\hline 6 & Drystone wall and rocks along a pathway & 45.16484 & 13.78428 \\
\hline 7 & Edges of a macadam pathway & 45.16006 & 13.77712 \\
\hline 8 & Macadam pathway & 45.16537 & 13.76449 \\
\hline 9 & Klaina Pond & 45.14760 & 13.76486 \\
\hline 10 & Juralska Pond & 45.14000 & 13.76804 \\
\hline 11 & Low forest dominated by Carpinus orientalis & 45.14153 & 13.78209 \\
\hline 12 & Low forest dominated by Carpinus orientalis & 45.13652 & 13.79873 \\
\hline 13 & Top of a rock exposed to sunlight & 45.13600 & 13.79812 \\
\hline 14 & Stone pit & 45.15260 & 13.78033 \\
\hline 15 & Macadam pathway & 45.15408 & 13.77327 \\
\hline 16 & Remnants of drystone wall on the edge of scrubland & 45.15247 & 13.77418 \\
\hline 17 & Rocks exposed to sunlight and a former fire site & 45.15393 & 13.77702 \\
\hline 18 & Arable field on the bottom of a doline & 45.15370 & 13.77811 \\
\hline 19 & Grassland & 45.15034 & 13.77976 \\
\hline 20 & Drystone wall between arable field and grassland & 45.15004 & 13.77549 \\
\hline 21 & Remnants of drystone wall between arable field and forest & 45.15047 & 13.77519 \\
\hline 22 & Arable field & 45.14962 & 13.77354 \\
\hline 23 & Plantation of Pinus halepensis and P. nigra & 45.15601 & 13.77339 \\
\hline 24 & Scrubland of Quercus pubescens & 45.16407 & 13.76577 \\
\hline 25 & Doline on the edge of scrub & 45.15521 & 13.77168 \\
\hline 26 & Site of a forest fire in a low stand of Quercus pubescens & 45.14551 & 13.77780 \\
\hline
\end{tabular}




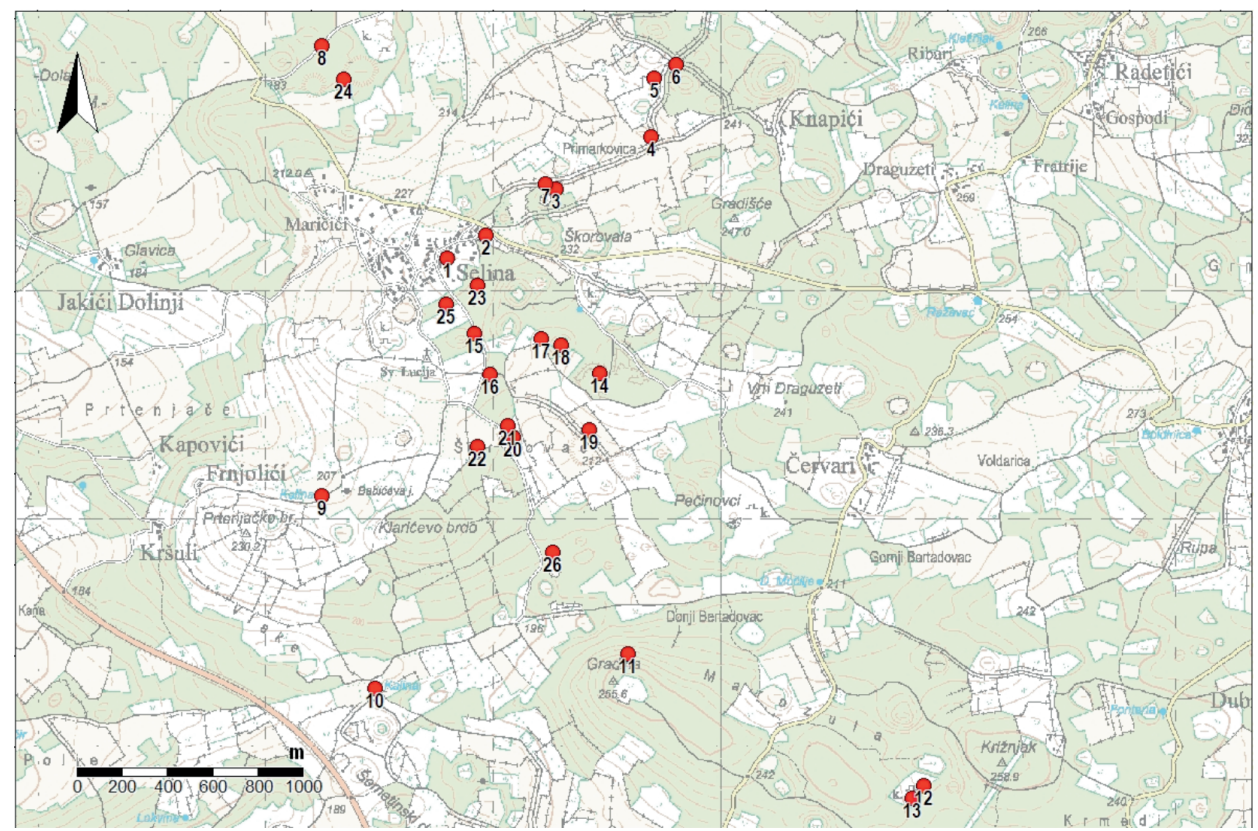

Fig. 2. Area of research: position of localities where bryophytes were collected.

\section{RESULTS}

This study in the area of Selina resulted in the finding of a total of 72 bryophytes, out of which 66 were mosses and 6 liverworts (Tab. 2).

The recorded taxa, depending on their distribution ranges according to main biomes, were grouped into eight main groups of floristic elements (Fig. 3). The highest number of taxa belong to the temperate element (25\%), i.e. to the biome of broadleaf forest zone, followed by the species of the boreo-temperate and the Mediterranean-Atlantic element (19.12\% each). The presence of southern temperate $(16.18 \%)$ and wide-temperate $(14.71 \%)$ elements is also significant, while the species of wide-boreal, boreal-montane and boreo-arctic element are present with low percentages. Though these percentages are low, the presence of these plants is important for the phytogeographic characterisation of the study area.

In the spectrum of distribution ranges regarding eastern limit categories (Fig. 4), the circumpolar element prevails (42.65\%), encompassing species with a broad area of distribution through extratropic parts of the Northern Hemisphere. The second most represented element is European (33.82\%), followed by suboceanic $(13.24 \%)$ and oceanic (5.88\%) elements. Eurosiberian and Eurasian elements are represented sporadically, with two and one species respectively. 


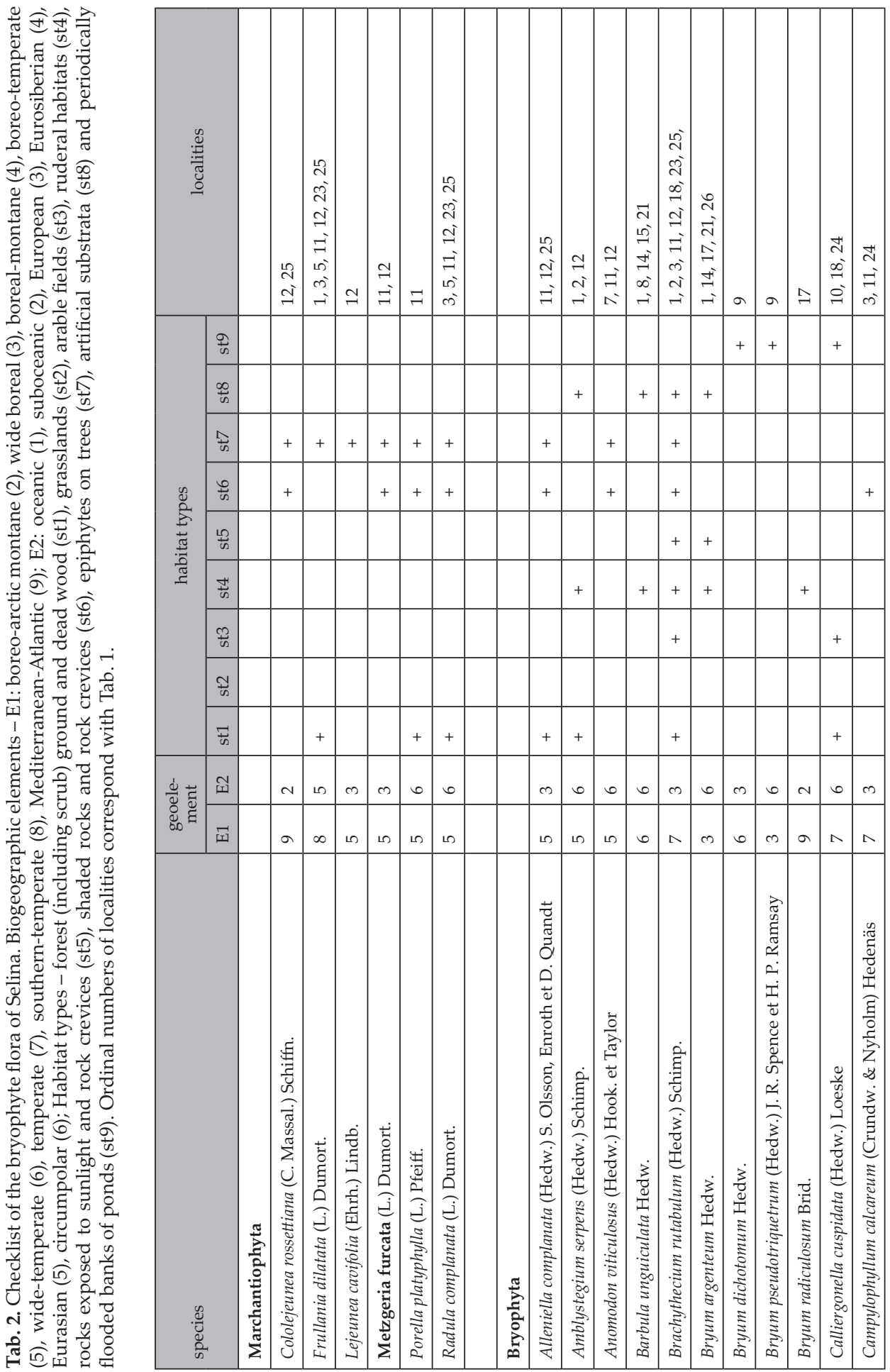




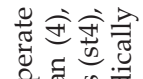

है. 동

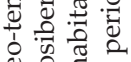

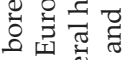

㐫穴焉

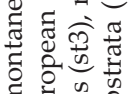

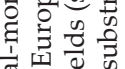

त्ञ

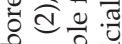

क्ञ

चु

के क्ष

龸

iิ.

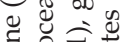

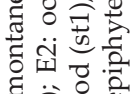

ชั

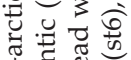

bै 등 \&

更记

월

讯

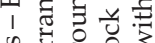

艺

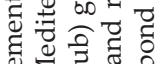

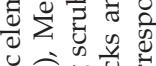

论

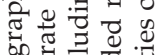

$00 \%$

$\infty$ 吾纪

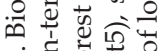

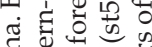
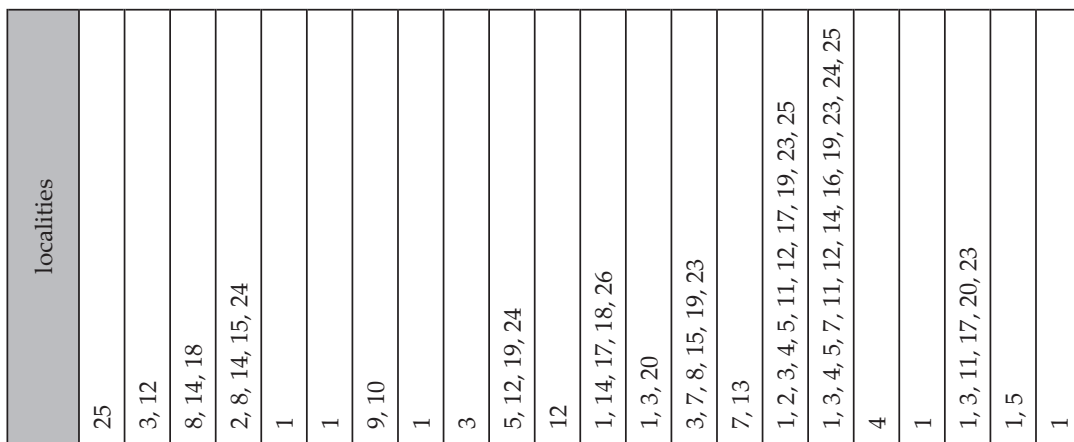

के 10 .

पे

동

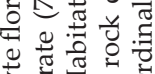

苋芯草

के द्व

D車

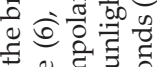

艺苛 क

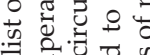

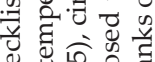

过论

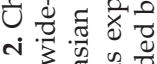

กิ่
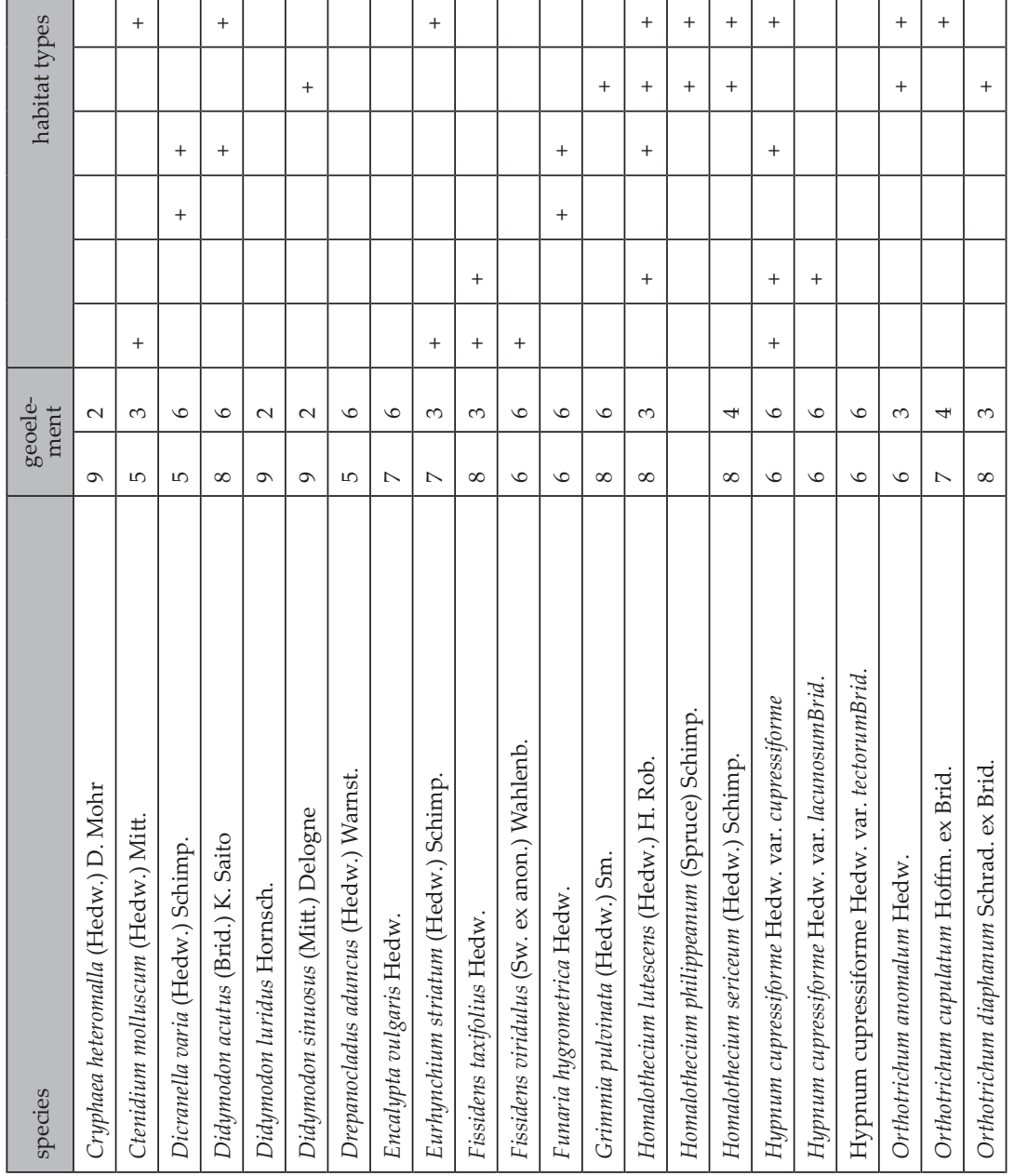


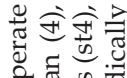

늘

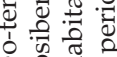

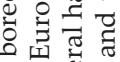

过官龸总

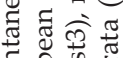

:

可훙

ปั่

कิ

ส

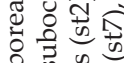

के के क

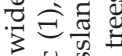

ลิ

\& \&

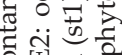

되융

可

प

b 증 क

专呵-

요웜

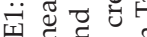

1 흘 चै

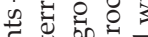

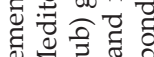

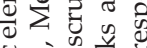

प्र 000

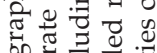

की

은 可

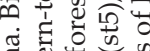

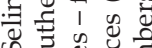

के

政

돈

윰

范茫

है हैं 记

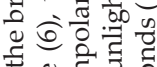
苛䒕菏吉

분

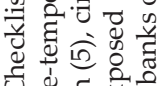

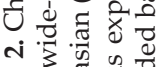

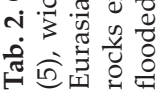

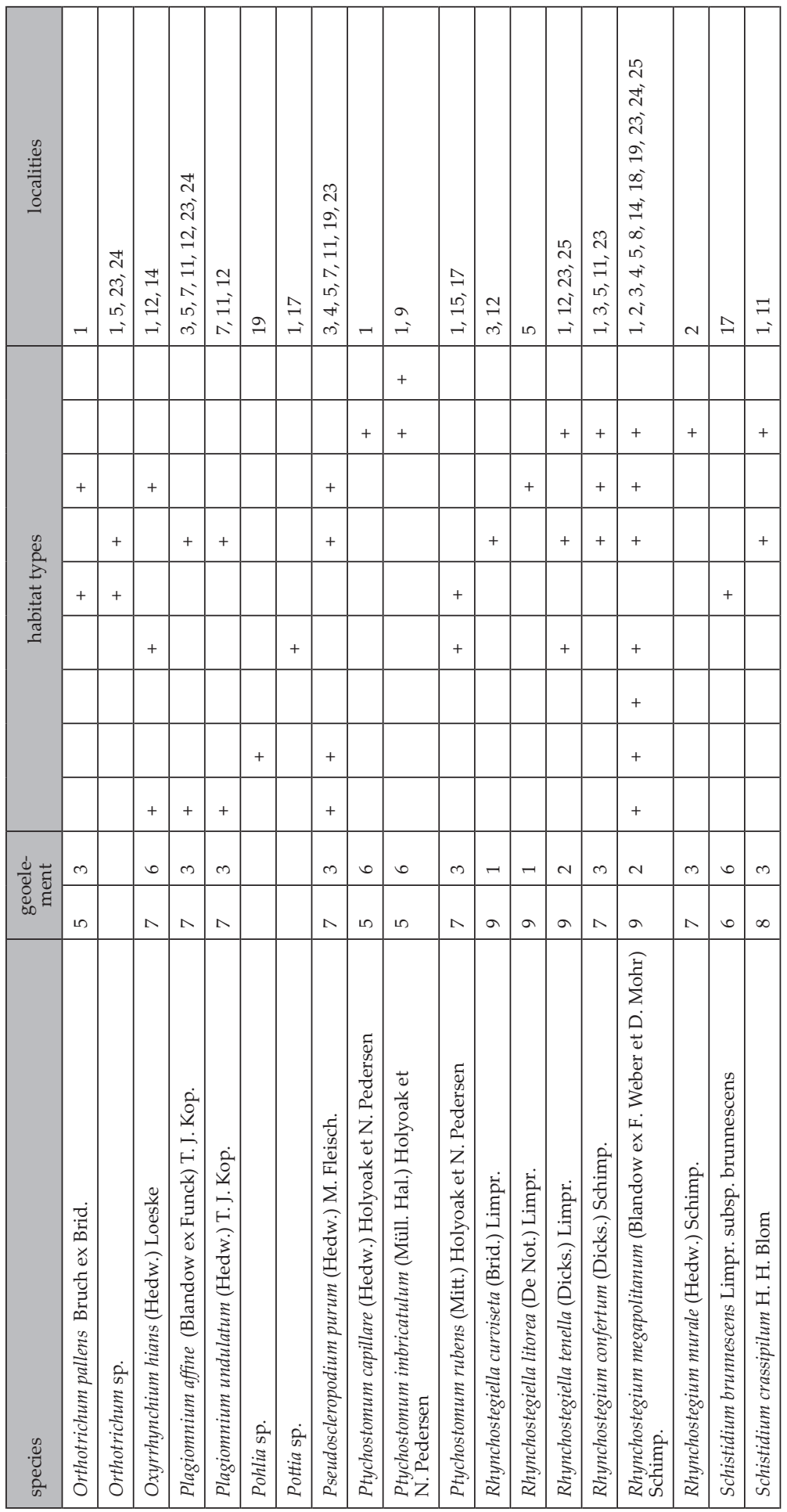




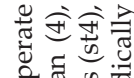

․․ㄹ

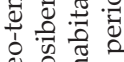

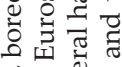

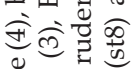

卷

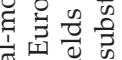

ब

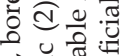

बิ

च

०क की

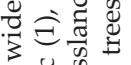

守范范

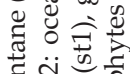

苛望苍总

范范

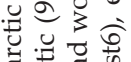

它䓠

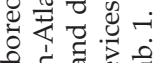

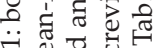

플

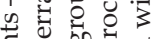

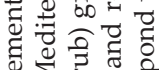

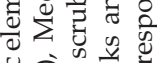

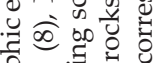

त्:

00 范

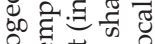

은

我苟通

毒声 1 过

पै क

可专政

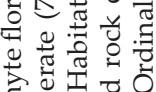

을 它宁

屯.

过家:

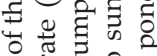

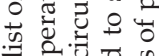

音

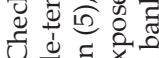

ㄴ.

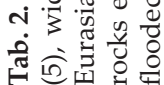

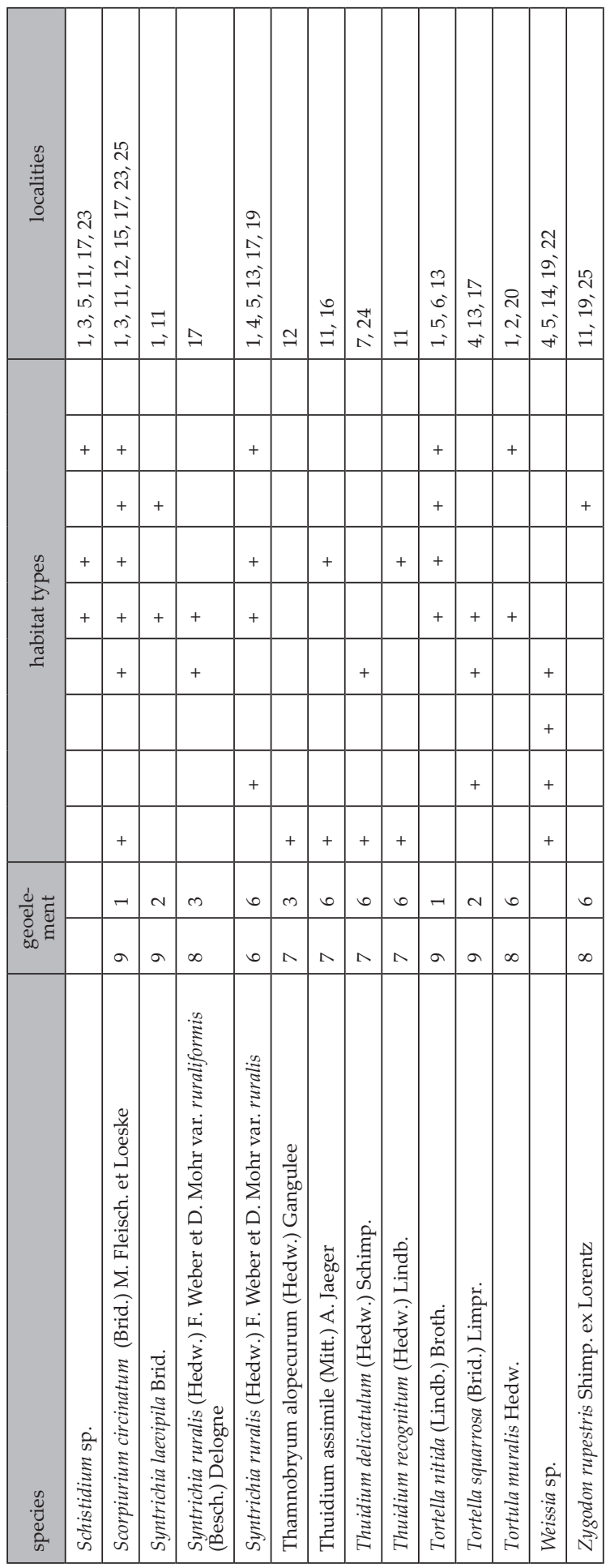



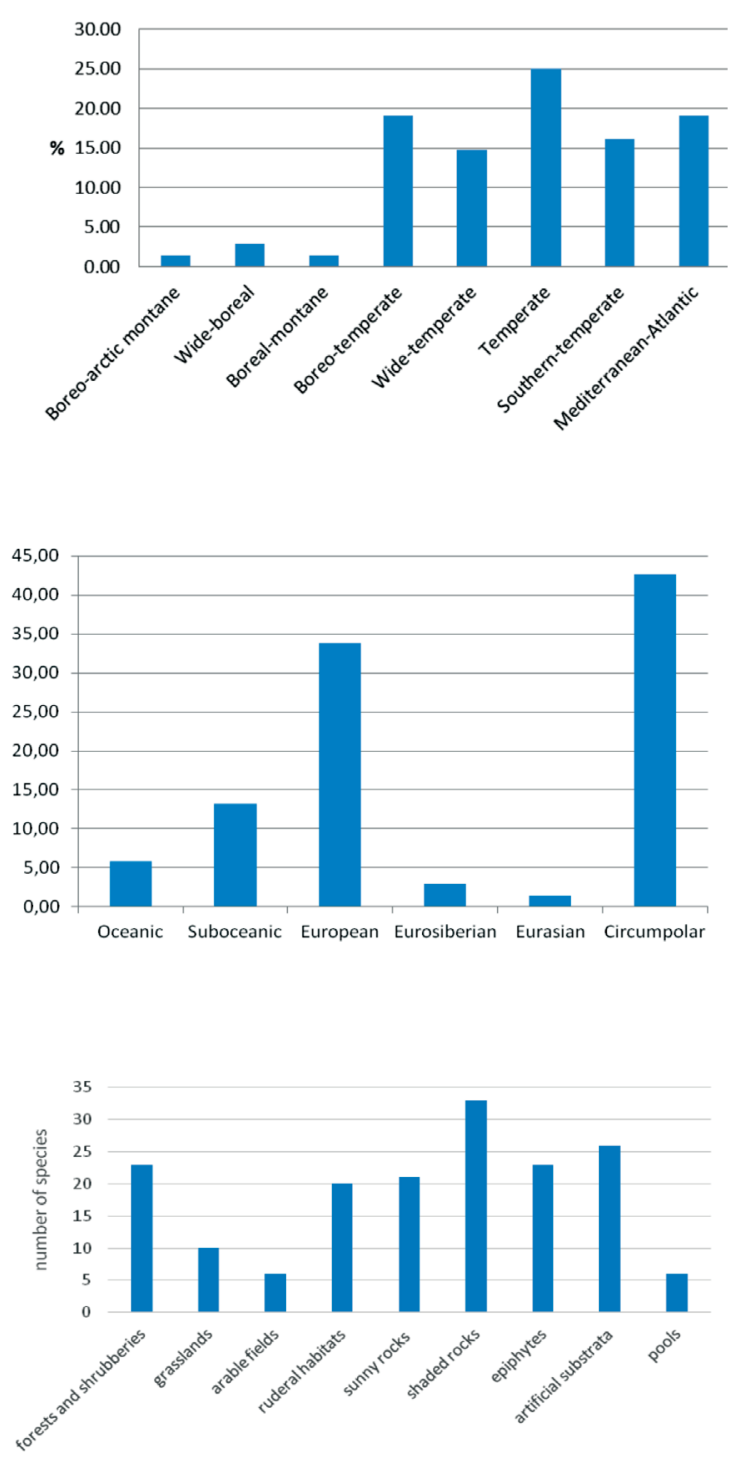

Fig. 3. Spectrum of biogeographic elements regarding major biomes in the bryophyte flora of Selina.

Fig. 4. Spectrum of biogeographic elements with respect to eastern limit categories in the bryophyte flora of Selina.

Fig. 5. Occurrence of bryophyte taxa in main habitat types in the area of Selina.

In terms of species richness, the highest numbers of species were found in the shaded rocks and rock crevices, where 33 species were recorded (Fig. 5), and on artificial substrata, where 26 species were recorded. These were followed by epiphytes, and forests and scrubland where 23 species were recorded in each type. On rocks exposed to sunlight and rock crevices 21 species were recorded, and a similar number (20) were found on ruderal habitats. The poorest habitat types regarding the species number are grasslands (10), arable fields (6) and periodically flooded banks of ponds (6). 


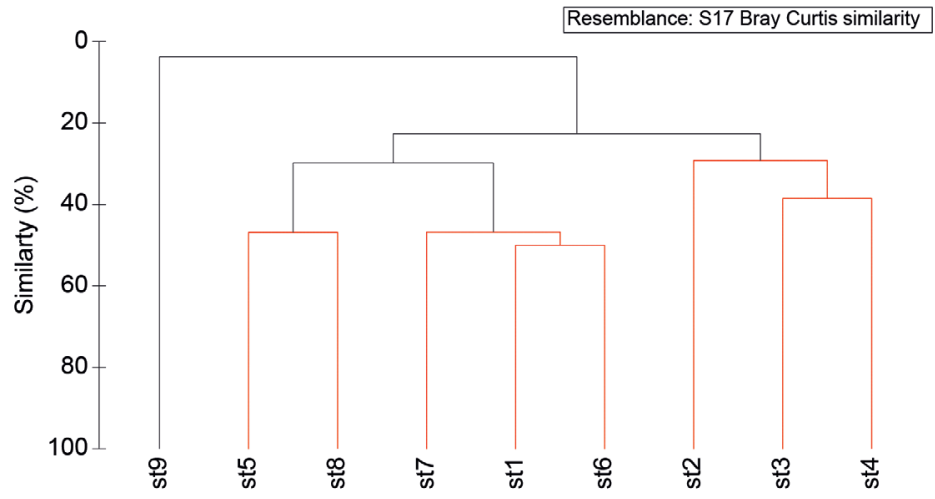

Fig. 6. Dendrogram representing similarity of habitats based on composition of bryophyte flora. Branchings in black are statistically significant and those in red are not based on Simproff test with 100 permutations. Habitat types: forest (including crub) ground and dead wood (st1), grasslands (st2), arable fields (st3), ruderal habitats (st4), rocks exposed to sunlight and rock crevices (st5), shaded rocks and rock crevices (st6), epiphytes on trees (st7), artificial substrata (st8) and periodically flooded banks of ponds (st9).

In order to compare bryophyte flora of different habitats, cluster analysis was performed (Fig. 6), resulting in four statistically significant groups - (1) periodically flooded banks of ponds, (2) rocks exposed to sunlight and crevices, and artificial substrata, (3) epiphytes, forests and scrubland and shaded rocks and crevices, and (4) grasslands, arable fields and ruderal habitats.

For further understanding of the relationship between the bryophytes and their habitats, NMDS analysis with passively projected vectors presenting Ellenberg's indicator values was performed (Fig. 7). As expected, periodically flooded banks of ponds are aligned toward the top of the vector presenting moisture, meaning that this habitat type is mostly characterised by hygrophilous species. On the other hand, species of arable fields show the highest requirements for soil fertility. Ruderal habitats, artificial substrata and rocks exposed to sunlight are aligned in the direction of the vector representing light, but they are evidently stretched along the vector representing soil reaction. This indicates that the species requiring higher $\mathrm{pH}$ value grow on natural limestone rocks, while and those adapted to lower $\mathrm{pH}$ inhabit ruderal habitats, and those of artificial substrata are situated in between. Forests and scrub, shaded rocks and epiphytes are situated on the opposite side of the light vector, with forest and scrubland moved into the direction of the vector representing moisture, indicating that these habitats encompass true forest species. 


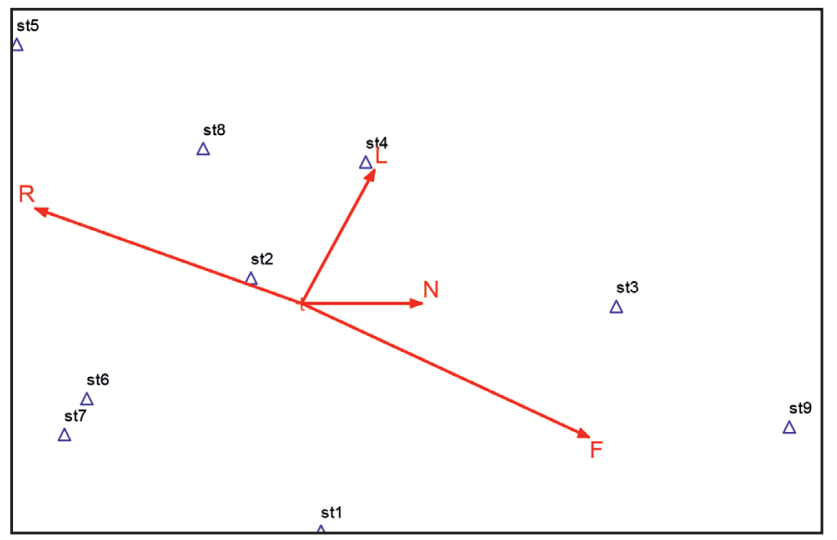

Fig. 7. NMDS ordination graph with passively projected vectors representing Ellenberg's indicator values. Habitat types: forest (including scrub) ground and dead wood (st1), grasslands (st2), arable fields (st3), ruderal habitats (st4), rocks exposed to sunlight and rock crevices (st5), shaded rocks and rock crevices (st6), epiphytes on trees (st7), artificial substrata (st8) and periodically flooded banks of ponds (st9). Vectors: light (L), moisture (F), environmental acidity $(\mathrm{R})$ and nitrogen or general fertility $(\mathrm{N}), 2 \mathrm{D}$ stress $=0.08$.

\section{DISCUSSION}

This work is the first comprehensive study of bryophyte flora in western Istria, resulting in a list of 72 species, which is a rather high number in comparison with some other areas in Croatia (PApp et al., 2013a, b; Alegro et al., 2014, 2015), taking into account the small size of the surveyed area. Only six species belonging to liverworts were recorded, probably due to their preference for a more humid climate (FraHm, 2001).

The phytogeographic analysis showed that the bryophyte flora of Selina is dominated by the temperate element $(25 \%)$, i.e. by species with their centre of distribution in the broadleaf forest zone. A considerable number of species belong to the boreo-temperate and Mediterranean-Atlantic element, followed by southern-temperate and wide temperate element, reflecting the biogeographic position of the studied area in the sub-Mediterranean zone, characterized by a mixture of Mediterranean and Atlantic species on one hand, and species of cooler zones on the other. The same is reflected by the elements describing the eastern limit of distribution. Apart from the clear dominance of broadly distributed species belonging to the circumpolar element, oceanic and suboceanic element together encompass almost $20 \%$ of species, clearly indicating the maritime influence on the research area. That there are over $30 \%$ of European species is also indicative of the biogeographic position of the area.

The highest number of species was recorded on shaded rocks and in rock crevices, which can be explained by the lack of competition with vascular plants. However, rocks exposed to sunlight exhibit a considerably lower number of species, due to the lower availability of water and the more variable general conditions. Interestingly, artificial substrata (concrete surfaces, roofs), which are 
another extreme habitat type, exhibit a relatively high number of species. This could be explained by the longer retention of water in such habitats in comparison with the natural limestone rocks. Another habitat type free from competition with vascular plants is tree bark. Compared to the shaded rocks, species richness on the forest ground is low. Vascular plants and especially litter decrease the surface suitable for the colonization of bryophytes. This is even more prominent in grasslands, where dense cover of grasses and other herbaceous species disable colonisation and persistence of many bryophyte species. Mechanical disturbance is the main reason for the relatively low bryophyte diversity in arable fields, while the absence of such disturbance allows the existence of considerably richer bryophyte flora in ruderal habitats. Banks of ponds are very specific habitats were only hygrophilous species can thrive.

The grouping of habitat types into four main clusters can be explained by analysing Ellenberg's indicator values of the corresponding species. The first group is represented by periodically flooded banks of ponds, inhabited by few, but highly specialised, species such as Drepanocladus aduncus, Ptychostomum pseudotriquetrum and some others. Two groups were defined based on light and moisture availability: dry open rocks exposed to sunlight and artificial substrata as one group, and forests with scrub, epiphytes and shaded rocks as another. Species with the lowest indicator values for light such as Campylophyllum calcareum and Rhynchostegiella curviseta thrive on shaded rocks. However, both on sunlightexposed and shaded rocks, species with the lowest indicator values for moisture are found (Grimmia pulvinata and Schistidium crassipilum). These rocky habitats also encompass the species with the highest values for soil reaction, since all rocks in the area are of limestone origin. The fourth group of habitats encompasses open secondary habitats with a pronounced anthropogenic influence, i.e. grasslands, arable fields and ruderal habitats. These habitats include species with a wide range of indicator values for soil reaction and nitrogen. That is, the highest and the lowest values for nitrogen are found in ruderal habitats and grasslands, respectively. All of the above indicates that this group of habitats is characterized by tolerant species with broad ecological niches.

\section{CONCLUSION}

This study revealed that even in a small area, bryophyte flora displays a biogeographical pattern which is in accordance with a biogeography based on vascular plants (Horvat et al., 1974; Šugar, 1984; Kaligarič, 1997; Terzi, 2011). However, the view is more general since bryophytes commonly show broader areas of distribution than vascular plants and lack local endemics (FRAHM, 2001). Nevertheless, a pattern throughout habitat types can be distinguished, revealing higher species richness in habitats with lower competition with vascular plants, and clearly showing a relationship between species requirements and environmental conditions. 


\section{REFERENCES}

Alegro, A., Papp, B., Szurdoki, E., Šmgota, V., Šapić, I. \& Vukelić, J., 2014: Contribution to the bryophytes flora of Croatia III. Plitvička jezera National Park and adjacent areas. Studia Botanica Hungarica 45, 49-65.

Alegro, A. \& Šmgota, V. \& PApp, B., 2015: A contribution to the bryophyte flora of Croatia IV: Žumberačka gora Mts. Studia Botanica Hungarica 46, 5-24.

Atherton, I., Bosanquet, S. \& Lawley, M., 2010: Mosses and Liverworts of Britain and Ireland - a field guide. British Bryological Society, Plymouth.

Bischler, H. \& Jovet-Ast, S., 1973: Une mission hépaticologique dautomne sur la côte yougoslave (Istrie, côte des îles dalmates, côte du Monténégro). Rev. Bryol. Lichenol. 39, 554-629.

Casas, C., Brugues, M., Cros, R. M. \& Sérgio, C., 2006: Handbook of mosses of the Iberian Peninsula and the Balearic Islands. Institut d'estudios Catalanas, Barcelona.

Clarke, K. R. \& Gorley, G. N., 2006: PRIMER v6: User Manual/Tutorial. PRIMER-E, Plymouth.

Düll, R., Ganeva, A., Martinčič, A. \& Pavletić, Z., 1999: Contributions to the bryoflora of former Yugoslavia and Bulgaria. Bryol. Beiträge 11, 1-99.

Erzberger, P.\& Schröder, W., 2013: The genus Bryum (Bryaceae, Musci) in Hungary. Studia bot. hung. 44, 5-192.

FILıPČı́́, A., 1998: Klimatska regionalizacija Hrvatske po Köppenu za standardno razdoblje 1961.1990. u odnosu na razdoblje 1931.-1960. Acta Geographica Croatica 33, 1-15.

Frahm, J.-P., 2001: Biologie der Moose. Spektrum \& G. Fischer Verlag, Heidelberg-Berlin.

Frahm, J.-P. \& Frey, W., 2004: Moosflora. \$. Auflage. Eugen Ulmer Verlag, Stuttgart.

Frey, W., Frahm, J.-P., Fischer, E. \& Lobin, W., 2006: The Liverworts, Mosses and Ferns of Europe. Harley Books, Colchester.

FreYn, J., 1877: Die Flora von Süd-Istrien. Verh. zool.-bot. Ges. Wien 27, 241-490.

GŁowAcKI, J., 1902: Beitrag zur Laubmoosflora der österreichischen Küstenlandes. Jahresb. Obergymn. Marburg 1902, 3-15.

Guerra, J., Cano, M.J. \& Ros, R.M., 2006: Flora Bríofitica Ibérica. Universidad de Murcia, Sociedad Española de Briología, Murcia.

Hill, M. O., Preston, C. D., Bosanquet, S. D. S. \& Roy, D. B., 2007: BRYOATT - Atributes of British and Irish Mosses, Liverworts and Hornworts. Centre for Ecology and Hydrology, Huntingdon.

Hoppe, D.H.\&Hornschum, F., 1817-18: Plantaecryptogamicaeselectae.Cent.1-22. Exsikkatensammlung, Regensburg.

Horvat, I., Glavač, V. \& Ellenberg, H., 1974: Vegetation Südosteuropas. Geobot. Select. IV. Gustav Fischer Verlag, Stuttgart.

Host, N., 1831: Flora austriaca II, Vindobonae.

Ignatov, M. S. \& Ignatova, E. A., 2003-2004: Flora mkhov srednej časti evropejskoj Rossii 1-2. KMK, Arctoa, Moskva.

Kaligarič, M., 1997: Rastlinstvo Primorskega krasa in Slovenske Istre - Travniki in pašniki. Zgodovinsko društvo za južno Primorsko, Znanstveno raziskovalno središče Republike Slovenije Koper, Koper.

Kern, F., 1896: Contributions a la flore bryologique de la peninsule de l'Istrie. Rev. Bryol. 22, 34-35.

Loitlesberger, K., 1905: Zur Moosflora der österreichischen Küstenländer. Verh. zool.-bot. Ges. Wien $55,475-489$.

Loitlesberger, K., 1909: Zur Moosflora der österreichischen Küstenländer II. Musci. Verh. zool.-bot. Ges. Wien 59, 51-67.

LÜTH, M., 2006-2011: Bidatlas der Moose Deutschlands. Eigenverlag, Freiburg.

MaIER, E., 2009: Grimmia in Europa: Ein Bestimmungsschlüssel. Herzogia 22, 229-302.

MatouscheK, F., 1900: Bryologisch-floristische Mitteilungen aus Österreich-Ungarn, der Schweiz, und Bayern I. Verh. zool.-bot. Ges. Wien 50, 219-254.

Mатоuscheк, F., 1901: Bryologisch-floristische Mitteilungen aus Österreich-Ungarn, der Schweiz, Montenegro, Bosnien u. Herzegovina II. Verh. zool.-bot. Ges. Wien 51, 186-198.

Matouscheк, F., 1904: Ein Zweiter Standort von Homalia lusitanica in österr.-ungarn. Monarchie. Magyar Bot. Lapok 3, 166.

Matouschek, F. 1905: Additamenta ad floram bryologicam Istrie et Dalmatie. Magyar Bot. Lapok 4, 24-27.

McCune, B. \& Mefford M. J., 2011: PcOrd. Multivariate analysis of ecological data. Version 6. MjM Software, Gleneden Beach, Oregon. 
Mucina, L., Bültmann, H., Dierssen, K., Theurillat, J.-P., Dengler, J., Čarni, A., Šumberová, K., Raus, T., Di Pietro, R., Gavílan García, R., Chytrý, M., Iakushenko, D., Schaminée, J. H. J., Bergmeier, E., Santos Guerra, A., Daniëls, F. J. A., Ermakov, N., Valachovic, M., Pignatti, S., Rodwell, J. S., Pallas, J., Capelo, J., Weber, H. E., Lysenko, T., Solomesh, A., Dimopolous, P., Aguiar, C., Freitag, H., Hennekens, S. M., Tichý, L., 2016: Vegetation of Europe: Hierarchical floristic classification system of plant, lichen, and algal communities. Applied Vegetation Science 19 (Suppl. 1), 3-264.

Nikolić, T. \& Topić, J., 2005: Crvena knjiga vaskularne flore Hrvatske. Ministarstvo kulture, Državni zavod za zaštitu prirode, Zagreb.

Onno, M., 1948: Prilog poznavanju kriptogamske flore Učke gore. (Beiträge zur Kenntnis der Kryptogamen-Flora der Učka Gora). Prir. istraž. Jugosl. Akad. 24, 75-83.

Papp, B., Alegro, A., Šegota, V., Šapić, I. \& Vukelić, J., 2013a: Additions to the bryophyte flora of Croatia. Journal of bryology 35 (2), 140-143.

Papp, B., Alegro, A., Šegota, V., Šapić, I. \& Vukelić, J., 2013b: Contribution to the bryophyte flora of Croatia II. The Northern Velebit. Studia botanica Hungarica 44, 213-228.

PAvletić, Z., 1955: Prodromus flore briofita Jugoslavije. Jugoslavenska akademija znanosti i umjetnosti, Posebna izdanja odjela za prirodne nauke, Knjiga III, Zagreb.

Pericin, C. \& Hürlimann, H. 2001: Beobachtungen zur vertikalen Verteilung der Moosarten in der Doline Sterna-Filaria im Karstgebiet von Buje/Buie in Istrien (Kroatien). Bauhinia 15, 91-96.

PoLšAK, A. \& ŠIKIĆ, D., 1969: Osnovna geološka karta SFRJ 1: 100 000, list Rovinj L 33-100. Institut za geološka istraživanja, Zagreb, Savezni geološki zavod, Beograd.

PolŠAK, A. \& ŠIKIĆ, D., 1975: Geološka skica Istre. In: RiĐAnović, J. et al., Geografija SR HrvatskeSjeverno Hrvatsko primorje. Institut za geografiju Sveučilišta u Zagrebu i Školska knjiga, Zagreb, p. 173.

Rabenhorst, L., 1844-53: Deutschlands Kryptogamenflora oder Handbuch zur Bestimmung der cryptogamische Gewächse Deutschlands, der Schweiz, der Lombardisch-venetianischen Königreichs und Istriens. Leipzig.

Ros, R. M., Mazimpaka, V., Abou-Salama, U., Aleffi, M., Blockeel, T. L., Brugués, M., Cano, M. J., Cros,R. M., Dia, M. G., Dirkse, G. M., El SaAdawi, W., ErdaĐ, A., Ganeva, A., González-Mancebo, J. M., Herrnstadt, I., Khalili, K., Kürschner, H., Lanfranco, E., Losada-Lima, A., Refai, M. S., Rodrígez-Nunéz, S., Sabovljević, M., Sérgio, C., Shabbara, H., Sim-Sim, M. \& Söderström, L., 2007: Hepatics and Anthocerotes of the Mediterranean, an annotated checklist. Cryptogamie Bryologie 28, 351- 437.

Ros, R. M., Mazimpaka, V., Abou-Salama, U., Aleffi, M., Blockeel, T. L., Brugués, M., Cros, R. M., Dia, M.G., Dirkse, G. M., Draper, I., El-SaAdawi, W., ErdaĞ, A., Ganeva, A., Gabriel, R., González-Mancebo, J. M., Granger, C., Herrnstadt, I., Hugonot, V., Khalili, K., Kürschner, H., Losada-Lima, A., Luis, L., Mifsud, S., Privitera, M., Puglisi, M., Sabovljević, M., Sérgio, C., Shabbara, H., Sim-Sim, M., Sotiaux, A., Tacchi, R., Vanderpoorten, A. \& Werner, O., 2013. Mosses of the Mediterranean, an annotated checklist. Cryptogamie Bryologie 34: 99 -283.

Rottensteiner, W. K., 2018: Die Pflanzen Istriens in ihren natürlichen Lebensräumen. Verlag des Naturwissenschaftlicen Vereins für Kärnten, Klagenfurt.

SchiffNer, V., 1909: Über Lebermoose aus Dalmatien und Istrien. Hedwigia 48, 191-202.

Schiffner, V., 1915: Neue Mitteilungen über Lebermoose aus Dalmatien und Istrien. Österr. Bot. Zeitschr. 65, 190-195.

Sendtner, O., 1857: Moose aus Kärnten, Görz, Krain, Istrien, Quarnerischen Inseln und Dalmatien. Verh. zool.-bot. Ges. Wien 7, 14-16.

Sмiтн, A. J. E., 1990: The Liverworts of Britain and Ireland. Cambridge University Press, Cambridge. Sмiтн, A. J. E., 2004: The Moss Flora of Britain and Ireland. Cambridge University Press, New York.

Solla, R. F., 1891: Bericht über einen Ausflug nach dem Südlichen Istrien. Österr. Bot. Zeitschr. 41, 324-327, 340-345.

Škvorc, Ž., Jasprica, N., Alegro, A., Kovačić, S., Franjić, J., Krstonošić, D., Vraneša, A. \& Čarni, A., 2017: Vegetation of Croatia: Phytosociological classification of the high-rank syntaxa. Acta botanica Croatica, 76 (2), 200-224.

ŠUgAR, I., 1984: Novi pogledi na biljni pokrov i biljnogeografsku rasčlanjenost Istre. Acta Bot. Croat. 43, 225-234.

Terzi, M., 2011: Nomenclatural Revision for the Order Scorzonero-Chrysopogonetalia. Folia Geobot. 46, 411-444.

Vukelić, J., 2012: Šumska vegetacija Hrvatske. Sveučilište u Zagrebu, Šumarski fakultet i Državni zavod za zaštitu prirode, Zagreb. 
Weiss, E., 1866: Floristisches aus Istrien, Dalmatien und Albanien. Verh. zool.-bot. Ges. Wien 16, 571584.

Weiss, E., 1867: Floristisches aus Istrien und Dalmatien. Verh. zool.-bot. Ges. 17, 753-762.

Zaninović, K., Gajić-Č́apka, M., Perčec Tadić, M., Vučetić, M., Milković, J., Bajić, A., Cindrić, K., Cvitan, L., Katušin, Z., Kaučić, D., Likso, T., Lončar, E., Lončar, Ž., Mihajlović, D., Pandžić, K., Patarčić, M., SRnec, L. \& Vučetić, V., 2008: Klimatski atlas Hrvatske/Climate atlas of Croatia 1961-1990., 1971.-2000. Državni hidrometeorološki zavod, Zagreb. 